\title{
FLOW DEPTHS AND VELOCITIES AT CREST AND LANDWARD SLOPE OF A DIKE, IN THEORY AND WITH THE WAVE OVERTOPPING SIMULATOR
}

\author{
Jentsje W. van der Meer ${ }^{1}$, Bianca Hardeman², Gosse-Jan Steendam³, Holger Schüttrumpf ${ }^{4}$ and \\ Henk Verheij ${ }^{5}$,
}

\begin{abstract}
Wave overtopping discharges at coastal structures are well described in the EurOtop Manual (2007), including the distribution of overtopping wave volumes. Each volume that overtops a dike or levee will have a certain flow velocity and depth record in time, often given by the maximum velocity and flow depth. This paper describes some further development of the theory on flow depth and velocities on the crest, but will also show an inconsistency with respect to the mass balance. The second part of the paper gives an analysis of measured values on real dikes, simulated by the Wave Overtopping Simulator. It gives also the method of "cumulative hydraulic load" to compare overtopping discharges for different wave conditions. A large wave height with less overtopping waves, but larger overtopping wave volumes, is more damaging than a small wave height with more, but smaller overtopping volumes, even if the overtopping discharge is similar. The reasons to develop the cumulative hydraulic load have been compared with the recently in the US developed method of erosional equivalence.
\end{abstract}

Keywords: dikes, levees, overtopping, flow depth, flow velocity, wave overtopping simulator, erosional index

\section{INTRODUCTION}

Small and large scale model testing is often applied to measure wave overtopping at coastal structures. This wave overtopping determines the crest height of dikes, levees, breakwaters and other structures. Severe wave overtopping may damage the crest and landward side of the dike or levee by the overtopping flow. The mean discharge, $\mathrm{q}$, and the distribution of overtopping wave volumes describe the wave overtopping for a main part. But each overtopping volume gives a flow depth and flow velocity at the crest and landward slope and each volume has a certain overtopping duration.

The Wave Overtopping Simulator (Van der Meer et al. 2006, 2007, 2008, 2009) simulates the overtopping wave tongues at the crest of a real dike and the development has been based on existing theory of flow depths and flow velocities. It appears, however, that this existing theory leads to a discrepancy and this discrepancy will be described in the paper.

It is not easy to measure flow depth and flow velocity in reality on a dike as the flow is very turbulent and a lot of air is entrapped. This is in contrast to small scale model testing. Conventional instruments seem not to be able to measure the flow accurately and therefore new, practical and robust, instruments have been developed. Measurements performed in March 2010 will be described and analyzed.

Finally, the effect of wave overtopping cannot be described by the wave overtopping discharge only. Severe (sea) wave conditions may give the same overtopping discharge as for much milder (river) wave conditions. In the first situation less waves overtop, but the overtopping wave volume (and consequently flow depth and velocity) is larger than for the mild condition, where many waves overtop with small overtopping wave volumes. A parameter or erosional index has to be developed which must be able to describe the different behaviour. This paper presents the "cumulative hydraulic load" and this has been compared with the developed theory on "erosional equivalence" by Dean et al. (2010).

\section{FLOW DEPTH AND FLOW VELOCITY}

\section{Distribution of Overtopping Wave Volumes}

Wave overtopping discharges at all kind of coastal structures are well described in the EurOtop Manual (2007), including the distribution of overtopping wave volumes. The overtopping discharge, $\mathrm{q}$, is simply the total volume of overtopped water (per unit length) in a certain duration, divided by this duration. There will be a certain number of overtopping waves that produce a distribution of overtopping wave volumes. The distribution is characterized by many small overtopping waves and a few much larger ones, see also the EurOtop Manual (2007). The distribution can be described by:

\footnotetext{
${ }^{1}$ Van der Meer Consulting BV, P.O. Box 423, 8440 AK, Heerenveen, NL, jm@vandermeerconsulting.nl

${ }^{2}$ Rijkswaterstaat, Centre for Water Management; NL; bianca.hardeman@rws.nl

3 Infram; NL; gosse.jan.steendam@infram.nl

${ }^{4}$ University of Aachen, DE; schuettrumpf@iww.rwth-aachen.de

${ }^{5}$ Delft University of Technology and Deltares; NL; henk.verheij@deltares.nl
} 


$$
\begin{gathered}
P_{V}=P(\underline{V} \leq V)=1-\exp \left[-\left(\frac{V}{a}\right)^{0.75}\right] \\
a=0.84 \cdot T_{m} \cdot \frac{q}{P_{o v}}=0.84 \cdot T_{m} \cdot q \cdot N_{w} / N_{o w}=0.84 \cdot q \cdot t / N_{o w}
\end{gathered}
$$

$\mathrm{P}_{\mathrm{V}}=$ probability of the overtopping volume $\underline{V}$ being smaller than $\mathrm{V}$

$\mathrm{V}=$ overtopping wave volume $\left(\mathrm{m}^{3} / \mathrm{m}\right)$

$\mathrm{T}_{\mathrm{m}}=$ mean wave period (s)

$\mathrm{q}=$ mean overtopping discharge $\left(\mathrm{m}^{3} / \mathrm{s}\right.$ per $\mathrm{m}$ width)

$\mathrm{N}_{\mathrm{w}}=$ number of incident waves

$\mathrm{N}_{\mathrm{ow}}=$ number of overtopping waves

$\mathrm{t}=$ duration of test or storm (s)

The overtopping wave volumes in reality occur randomly in time. Figures 1 and 2 show the overtopping wave volumes in time as they were simulated by the Wave Overtopping Simulator. Tests were performed with $0.1 ; 1 ; 5 ; 10 ; 30 ; 50$ and $751 / \mathrm{s}$ per $\mathrm{m}$ overtopping discharge and each test condition was kept for 6 hours. The difference between Figures 1 and 2 is that Figure 1 was produced for a significant wave height of $1 \mathrm{~m}$ (river dikes), peak period of $4 \mathrm{~s}$, and Figure 2 for a wave height of $3 \mathrm{~m}$ (sea waves), peak period of $6.9 \mathrm{~s}$. There is a large difference between the two conditions, in number of overtopping waves and overtopping wave volumes, caused by the difference in wave heights and periods.

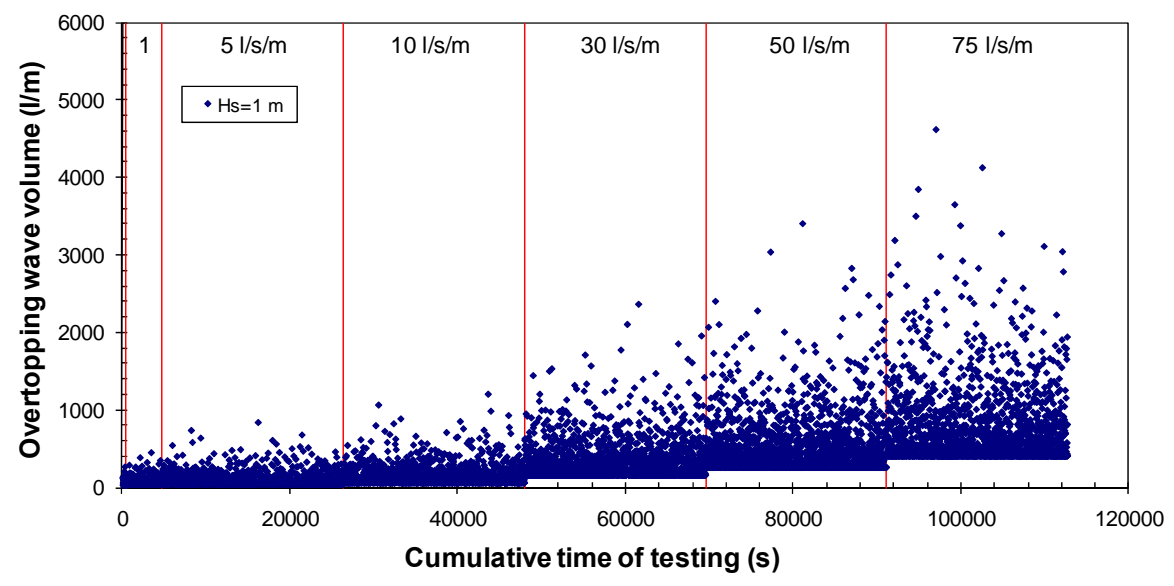

Figure 1. Overtopping wave volumes for various discharges and $H_{s}=1 \mathrm{~m}$ with $T_{p}=4 \mathrm{~s}$

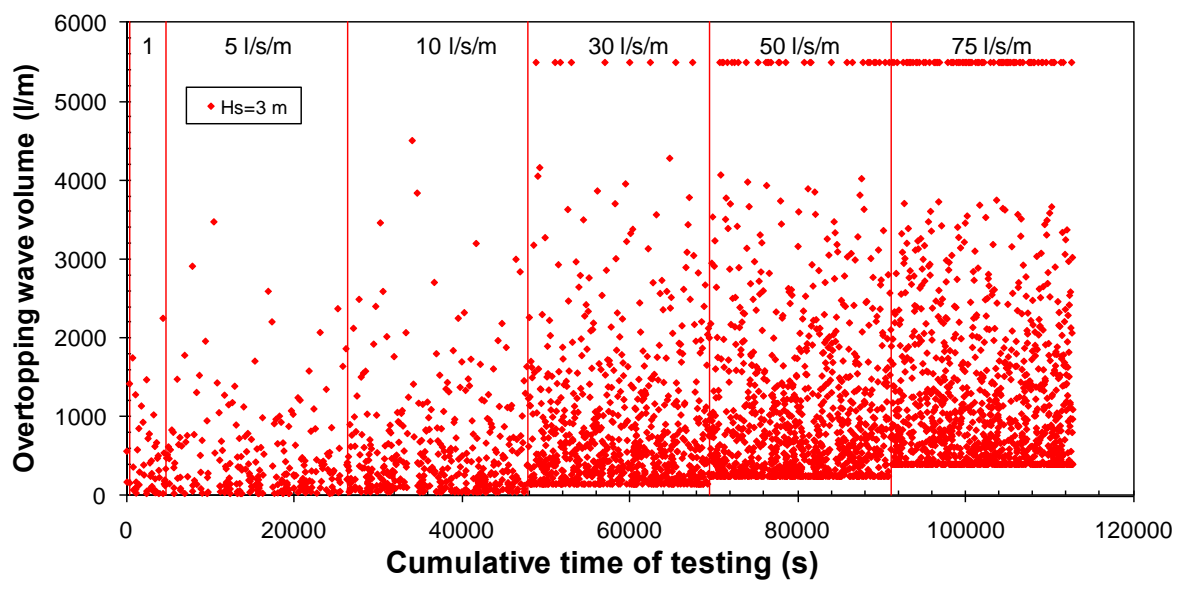

Figure 2. Overtopping wave volumes for various discharges and $H_{s}=3 \mathrm{~m}$ with $T_{p}=6.9 \mathrm{~s}$ 


\section{Existing Equations of Flow Depth and Flow Velocity}

Equations for flow depth and velocity have been based on physical model investigations like by Schüttrumpf (2001, 2005) and Van Gent (2002), published as a joined paper in Schüttrumpf and Van Gent (2003). The problem at that time was that the flow depth predicted by Schüttrumpf was twice the one by Van Gent. For this reason the Wave Overtopping Simulator in 2006 was designed on flow velocity and not on flow depth. The EurOtop Manual (2007) also gives the equations.

Bosman et al. (2008) investigated this discrepancy and discovered that the difference in predicted flow depth could possibly be explained by the different seaward slopes (1:4 and 1:6) used by the different authors. He used a sin $\alpha$ to combine the equations. Bosman also studied flow depth and flow velocity on the crest of a dike or levee, and finally he looked at the flow time.

The basic equations for (maximum) flow depth and velocity are:

where:

$$
\begin{aligned}
& \mathrm{h}_{2 \%}\left(\mathrm{x}_{\mathrm{c}}=0\right)=\mathrm{c}_{\mathrm{A}, \mathrm{h}}\left(\mathrm{R}_{\mathrm{u} 2 \%}-\mathrm{R}_{\mathrm{c}}\right) \\
& \mathrm{u}_{2 \%}\left(\mathrm{x}_{\mathrm{c}}=0\right)=\mathrm{c}_{\mathrm{A}, \mathrm{u}}\left(\mathrm{g}\left(\mathrm{R}_{\mathrm{u} 2 \%}-\mathrm{R}_{\mathrm{c}}\right)\right)^{0.5}
\end{aligned}
$$

$\mathrm{h}_{2 \%}=$ flow depth exceeded by $2 \%$ of the incident waves [m]

$\mathrm{u}_{2 \%}=$ flow velocity exceeded by $2 \%$ of the incident waves $[\mathrm{m} / \mathrm{s}]$

$\mathrm{x}_{\mathrm{c}}=$ location on the crest $\left(\mathrm{x}_{\mathrm{c}}=0\right.$ is the transition from seaward slope to the crest $)[\mathrm{m}]$

$\mathrm{c}_{\mathrm{A}, \mathrm{h}}=$ coefficient for the flow depth [-]

$\mathrm{c}_{\mathrm{A}, \mathrm{u}}=$ coefficient for the flow velocity [-]

$\mathrm{R}_{\mathrm{u} 2 \%}=2 \%$ wave run-up level [m]

$\mathrm{R}_{\mathrm{c}}=$ crest freeboard (vertical distance between crest and stil water level)) [m]

The coefficients where found as in Table 1. The Overtopping Simulator was designed with $\mathrm{c}_{\mathrm{A}, \mathrm{u}}=1.35$.

\begin{tabular}{|l|c|c|}
\hline \multicolumn{3}{|l|}{ Table 1. Coefficients in Equations (3) and (4) } \\
\hline Author & $C_{A, h}$ & $C_{A, u}$ \\
\hline Schüttrumpf (2001,2005) & 0.33 & 1.37 \\
\hline Van Gent (2002) & 0.15 & 1.33 \\
\hline Bosman (2007) & $0.010 / \sin ^{2} \alpha$ & $0.30 / \sin \alpha$ \\
\hline Bosman (2007) 1:4 & 0.17 & 1.24 \\
\hline Bosman (2007) 1:6 & 0.37 & 1.82 \\
\hline
\end{tabular}

\section{Flowdike developments}

The Flowdike project has been executed under the European Union programme Hydalab III. The objective was to investigate the influence of currents along a dike on wave run-up and wave overtopping. Leading partner was the University of Aachen in Germany. The tests were performed in the wave-current basin of the Danish Hydraulic Institute, DHI, at Hørsholm, see Figure 3.

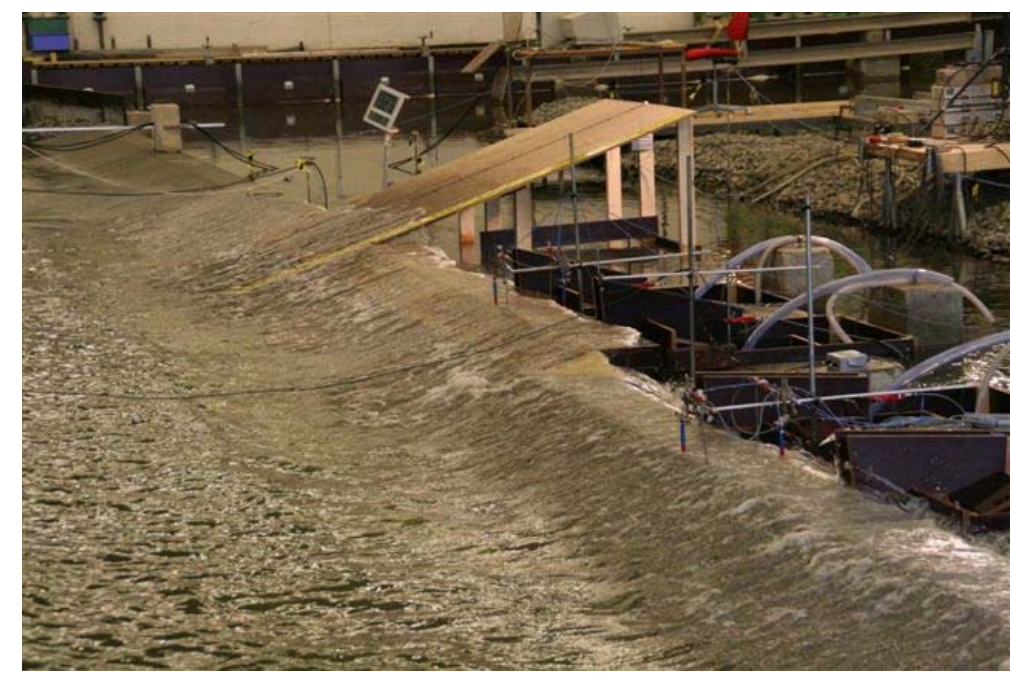

Figure 3. Overall view of the Flowdike model with two crest heights and the run-up board. 
The experimental investigations were performed for a simple 1:3 slope, typical for river dikes. The slope was divided into two separate parts to perform wave run-up and wave overtopping tests at the same time. The overtopping tests were performed on slope sections with crest freeboards of $0.1 \mathrm{~m}$ and $0.2 \mathrm{~m}$. The crest width was $0.30 \mathrm{~m}$. Flow velocities and flow depths were measured at the transition from seaward slope to the crest and $0.30 \mathrm{~m}$ behind this point, at the end of the crest.

The slope of 1:3 is steeper than the slopes of Van Gent (1:4) and Schüttrumpf (1:6). Bosman et al. (2008) used a $\sin \alpha$ in his equations (Equations 3 and 4), which for fairly gentle slopes is almost equal to the more often used cot $\alpha$. The extra data by the Flowdike project showed that the flow depth $h_{2 \%}$ could not be described by Equation (3) as the data for the 1:3 slope fell in between the data for the 1:4 and 1:6 slope. But the influence of slope angle was clearly visible for the flow velocity $\mathrm{u}_{2 \%}$. Figure 4 gives all data for the flow depth and Figure 5 for the flow velocity. Note that data with "Conf. A-D"' belong to Van Gent (2002).

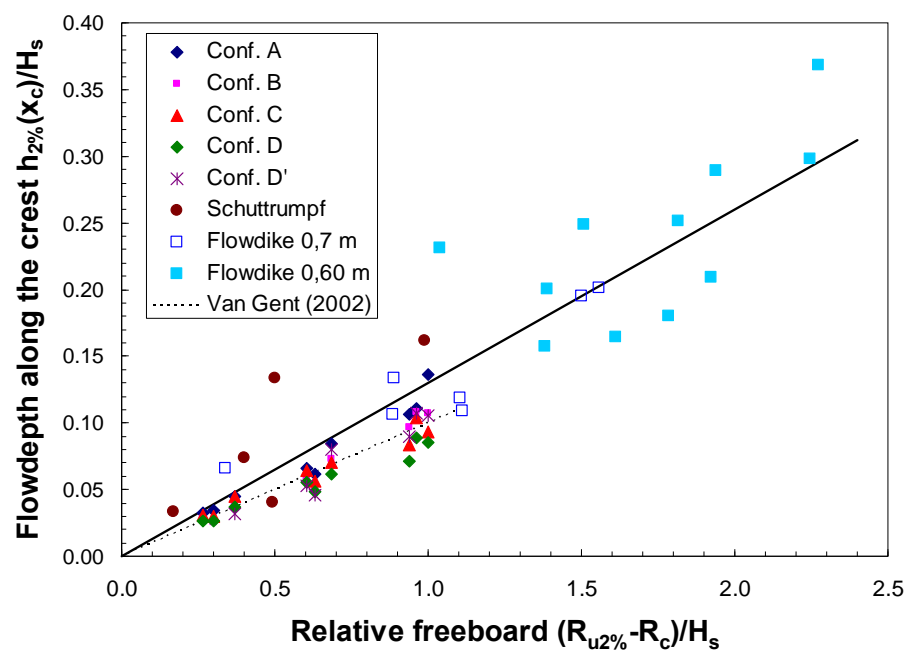

Figure 4. Flow depth at the landward crest, including Flowdike data.

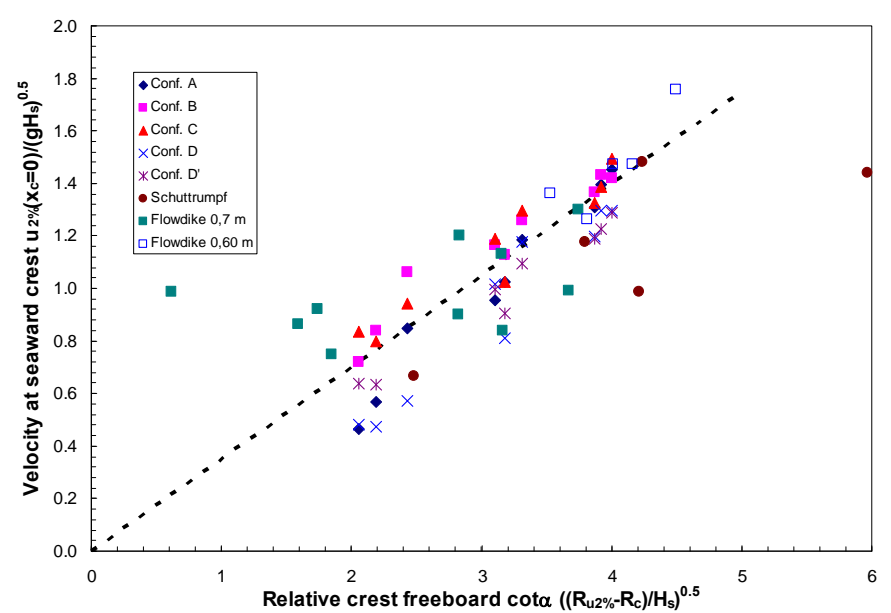

Figure 5. Flow velocity at the seaward crest, including the seaward slope cota.

The analysis led to the following summary of equations for flow velocity and flow depth on and along the crest of a dike, with a smooth slope. The flow depth reduces directly behind the seaward crest and remains then almost constant along the crest. This flow depth along the crest is given in Figure 4 and Equation 5. The flow depth at the seaward crest is 50\% larger than given in Equation 5.

$$
\mathrm{h}_{2 \%}\left(\mathrm{x}_{\mathrm{c}}\right)=0.13\left(\mathrm{R}_{\mathrm{u} 2 \%}-\mathrm{R}_{\mathrm{c}}\right)
$$

The flow velocity on the seaward crest is given in Figure 5 and can be described by Equation 6 :

$$
\mathrm{u}_{2 \%}\left(\mathrm{x}_{\mathrm{c}}=0\right)=0.35 \cot \alpha\left(\mathrm{g}\left(\mathrm{R}_{\mathrm{u} 2 \%}-\mathrm{R}_{\mathrm{c}}\right)\right)^{0.5}
$$


The decay of flow velocity along the crest is given by Equation 7:

$$
\mathrm{u}_{2 \%}\left(\mathrm{x}_{\mathrm{c}}\right) / \mathrm{u}_{2 \%}\left(\mathrm{x}_{\mathrm{c}}=0\right)=\exp \left(-1.4 \mathrm{x}_{\mathrm{c}} / \mathrm{L}_{\mathrm{m}-1,0}\right)
$$

\section{Discrepancy in equations}

By assuming a Rayleigh distribution for the flow velocity (Equation 6) and flow depth (Equation 5) the velocity and flow depth can be calculated for each overtopping wave volume with a certain probability of exceedance. Such calculations lead to graphs of flow velocity or flow depth versus overtopping wave volume. Figure 6 gives these graphs for an $8 \mathrm{ft}(2.4 \mathrm{~m})$ wave condition.

Curves are found for each overtopping discharge, which ranges from $0.1-2.0 \mathrm{cfs} / \mathrm{ft}$ (almost equal to $10-200 \mathrm{l} / \mathrm{s}$ per $\mathrm{m}$ ). But the curves deviate from each other and for the same overtopping wave volume lower flow velocities and flow depths are found if the overtopping discharge increases. And the same happens for the flow duration. This is physically not possible as a decrease in flow velocity should result in an increase in flow depth or flow duration (mass balance).

It must be concluded that present knowledge and prediction formulae for flow velocity, flow depth and flow duration do not yet give consistent answers. More research is required to solve this discrepancy and probably the flow depth and velocity must become more dependent on wave period. Also the assumption about both flow depth and flow velocity having a Rayleigh distribution may be questioned.
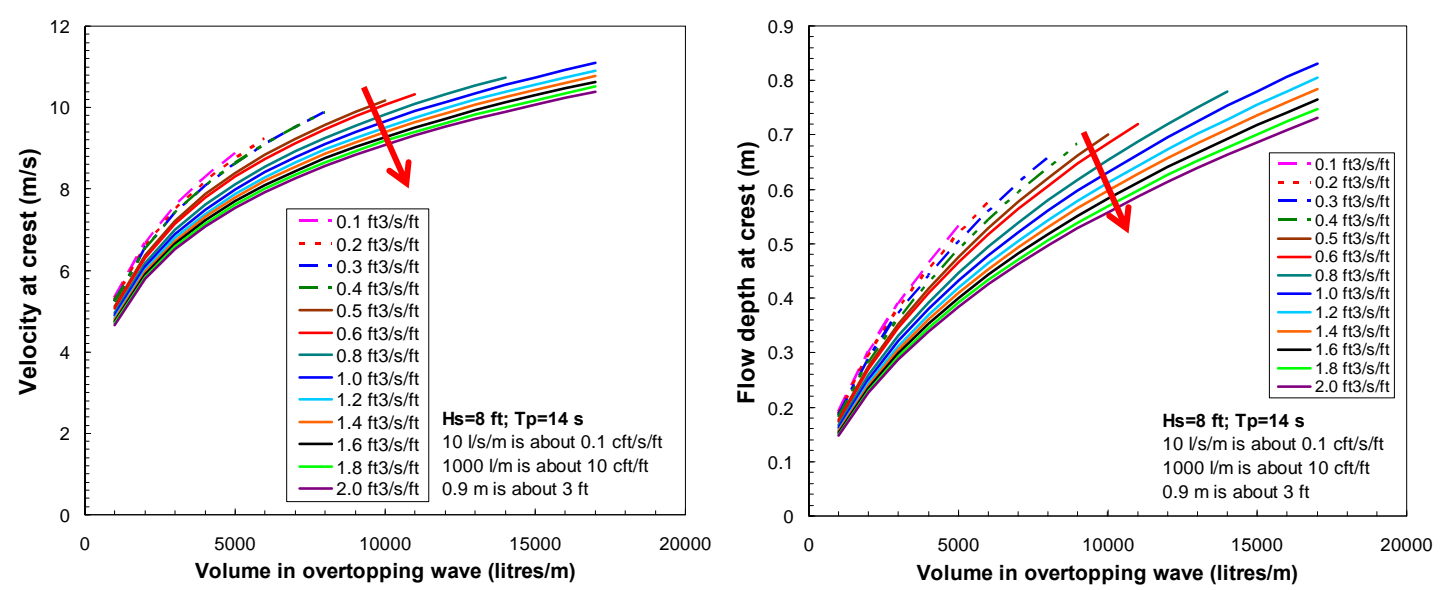

Figure 6. Flow velocity and flow depth at the seaward crest versus overtopping wave volume for a condition of $H_{m 0}=8 \mathrm{ft}(2.4 \mathrm{~m})$ and $T_{p}=14 \mathrm{~s}$. A similar volume may gave different values.

\section{HYDRAULIC MEASUREMENTS ON A REAL DIKE}

\section{Test Set-up}

The actual tests on erosion resistance of a sandy river dike have been described by Steendam et al. (2010). A special test was performed on a separate dike section, where the purpose was to measure hydraulic parameters only like flow depth, velocity and overtopping duration. The test consisted of three times repeated overtopping wave volumes, which increased in time from $200 \mathrm{l} / \mathrm{m}$ to $5,5001 / \mathrm{m}$ (the maximum capacity of the Wave Overtopping Simulator).

Five "surf boards" were placed along the slope, see Figure 7. These surfboards are able to measure the flow depths (see Van der Meer et al. 2009). They are hinged on one side and the rotation of the surfboard, floating on top of the flow, is measured by a potentiometer. A new development is the use of a "paddle wheel" in this surfboard to measure the flow velocity. This paddle wheel is often used in small boats to measure their velocity in the water. As this was a new development and results were not guaranteed, only three paddle wheels were bought and installed. Two were installed in surfboards and one upside down on a plate in the soil. This last one measured the flow directly at the bottom, the others at the top of the flow.

Measurements were made from the inner crest line (at the transition to the landward slope) and $12 \mathrm{~m}$ along the slope. The slope was not completely straight, the upper part was 1:3.7 and the lower part 1:5.2. Surfboard 1 was located at the crest and surfboard 5 at the down slope. 

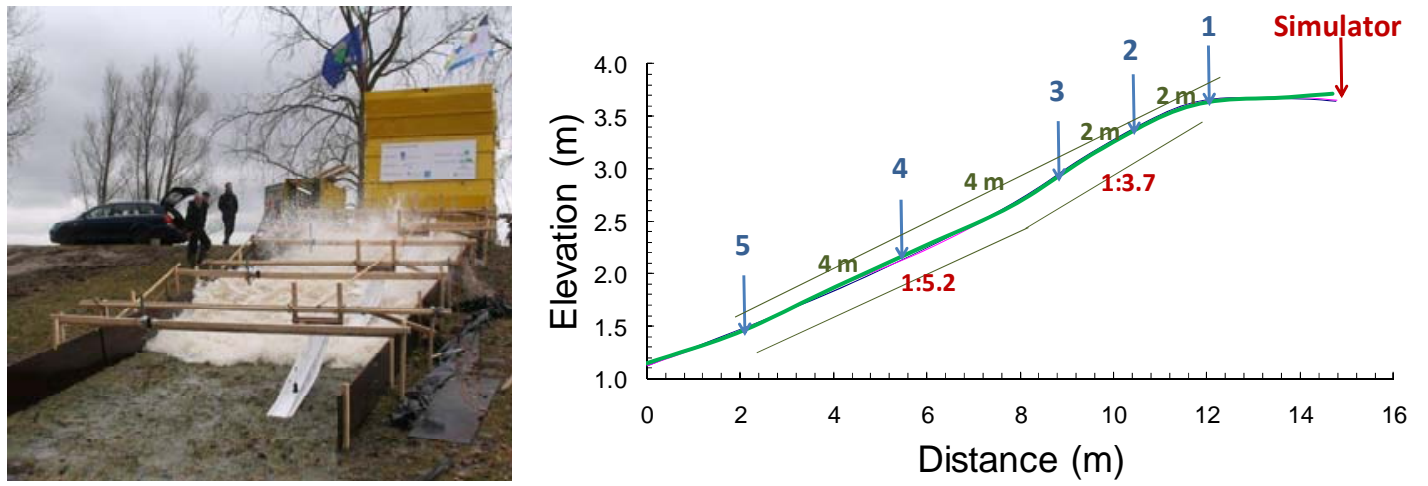

Figure 7. Test set-up with five surfboards for special measurements of flow depth, flow velocity and overtopping duration.

\section{Measured records}

The first analysis of measurements was to see what kind of records were obtained and if they made sense. Figure 8 shows the flow depth along the slope for an overtopping wave volume of $3000 \mathrm{l} / \mathrm{m}$ and the flow velocity along the slope for a volume of $1000 \mathrm{l} / \mathrm{m}$. In general nice signals were recorded.

The (maximum) flow depth seems to decrease a little along the slope. The flow velocity for the paddle wheel at surfboard 3 and at the same location at the soil start at the same time, but the flow velocity at the soil is a little smaller as it is in the boundary layer of the flow.
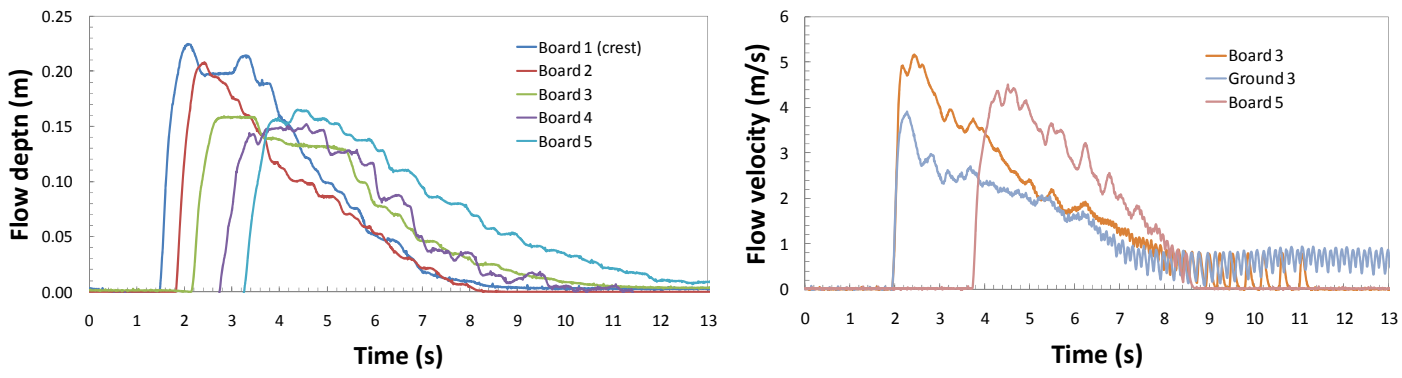

Figure 8. Records of flow depth and flow velocity along the slope.

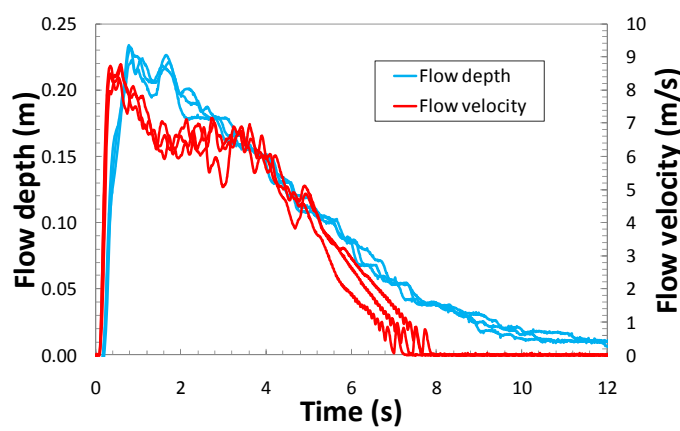

Figure 9 shows records of the flow depth and flow velocity for surfboard 5 (see Figure 7 for the location). The records are shown for an overtopping wave volume of $5000 \mathrm{l} / \mathrm{m}$ and for three waves that were repeated. The graph shows that a similar overtopping wave volume gives similar records and that the repeatability of the measurements is quite good.

Figure 9. Records for three overtopping wave volumes of $5000 \mathrm{I} / \mathrm{m}$.
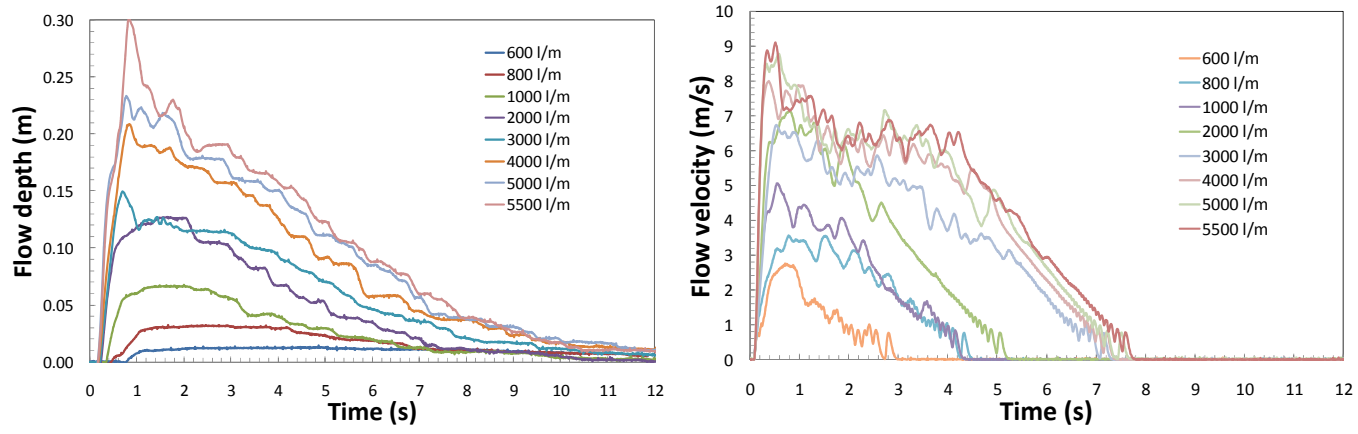

Figure 10. Flow depths and flow velocities for different overtopping wave volumes (surfboard 5). 
Figure 10 was composed by putting the records of various overtopping wave volumes in one graph. The graphs show the development in flow depth and flow velocity from small overtopping wave volumes to the largest ones of 5,500 $\mathrm{l} / \mathrm{m}$. They were measured at surfboard 5. Flow depth increases with increasing volume, where the rise time to the peak is very short. Note that the overtopping time for small overtopping volumes is quite large. In fact these small overtopping volumes slow down along the grassed slope, a phenomenon that cannot or hardly be reproduced in a small scale model.

Also the flow velocities increase with increasing overtopping wave volumes. Maximum velocities of $9 \mathrm{~m} / \mathrm{s}$ were reached. The paddle wheel reaches its maximum within tenths of seconds and responds very quickly. The overtopping durations measured with the paddle wheel seem shorter than measured for flow depth. The reason is that the paddle wheel was mounted a little above the ground and was not able to measure velocities in small flow depths. Where the surfboard measures flow depths of a few centimeters, the paddle wheel becomes dry.

\section{Analysis of measurements}

Figure 11 gives the (maximum) flow depth, h, versus the released overtopping wave volumes and for all five surfboards along the slope. The flow depth at the crest and also directly behind the crest is larger than further down the slope. It remains the same from 8-12 m from the crest, which may be explained by the changing slope angle after surfboard 3, see also Figure 7. The flow depth at the crest, mainly fitted on the larger overtopping wave volumes, can be given as (note coefficient 0.133 is not dimensionless):

$$
\mathrm{h}=0.133 \mathrm{~V}^{0.5} \quad\left(\mathrm{~h} \text { in } \mathrm{m} ; \mathrm{V} \text { in } \mathrm{m}^{3} / \mathrm{m}\right)
$$

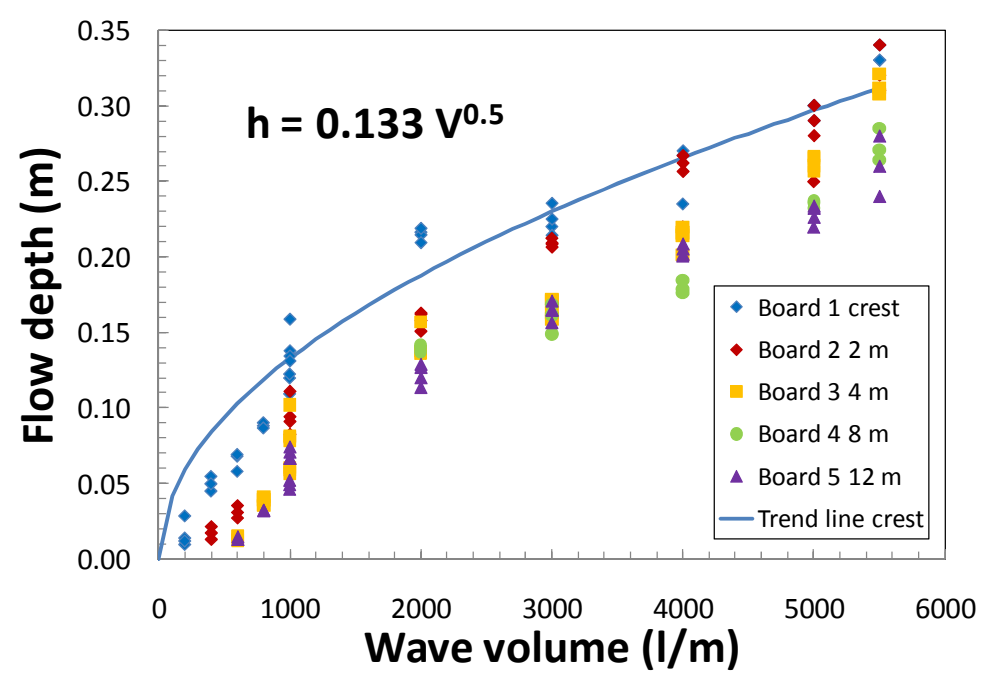

Figure 11. Flow depths along the slope as function of overtopping wave volumes.

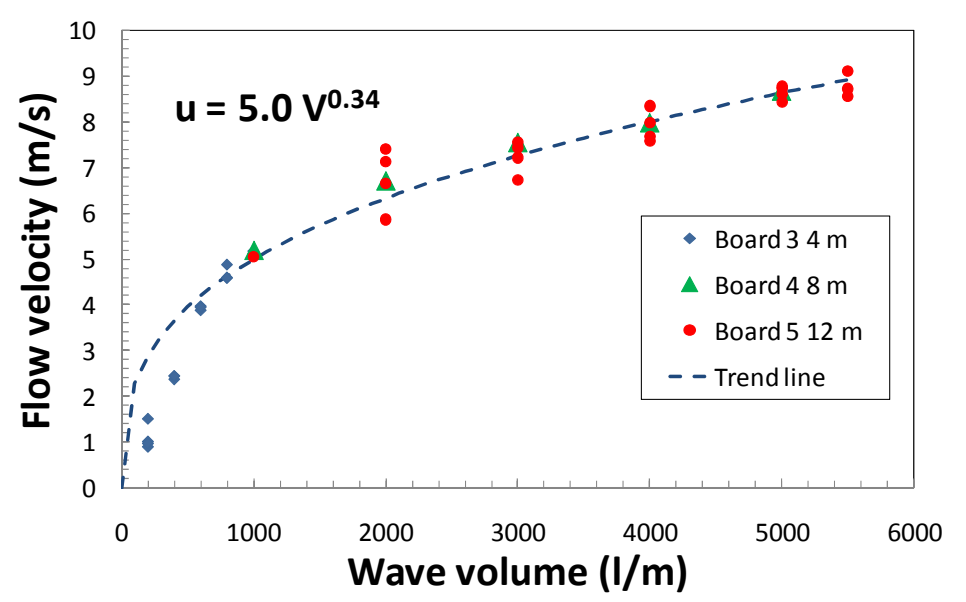

Figure 12. Flow velocities along the slope as function of overtopping wave volumes. 
A similar graph was made in Figure 12, but now for the (maximum) flow velocities, $\mathrm{u}$. There were only a few paddle wheels, but it seems that the velocity along the slope did not change significantly. All measurements form together a nice line and can be given by:

$$
\mathrm{u}=5.0 \mathrm{~V}^{0.34} \quad\left(\mathrm{u} \text { in } \mathrm{m} / \mathrm{s} ; \mathrm{V} \text { in } \mathrm{m}^{3} / \mathrm{m}\right)
$$

The paddle wheels in the surfboard measured the flow velocity on top of the flow. One paddle wheel was mounted upside down in the soil, in a flat and smooth plate. This paddle wheel measures part of the boundary layer and a comparison with the velocity on top of the flow may indicate the size of the boundary layer. Figure 13 is similar to Figure 12, but now the measurements at the ground/soil have been added.

For velocities up to $3 \mathrm{~m} / \mathrm{s}$ (wave overtopping volumes up to $500 \mathrm{l} / \mathrm{m}$ ) there is no difference between the ground level and the top of the flow. There is hardly a boundary layer in that case and the measured velocities can be considered as the depth-averaged velocities. For larger velocities and overtopping wave volumes it is clear that the velocity at ground level is smaller than at the top of the flow. Maximum velocities at ground level are about $5 \mathrm{~m} / \mathrm{s}$ and at the top of the flow about $9 \mathrm{~m} / \mathrm{s}$.

But still $5 \mathrm{~m} / \mathrm{s}$ is a large velocity very close to the ground level (the paddle wheel measures about $5 \mathrm{~mm}$ flow). It can be concluded that when flow velocities are smaller than $3 \mathrm{~m} / \mathrm{s}$ (flow depths smaller than about $0.05 \mathrm{~m}$ ), there is no boundary layer of significance. For larger velocities and flow depths it seems that the boundary layer is not much larger than a few centimeters, as the velocity in the first $5 \mathrm{~mm}$ from ground level is already $60-70 \%$ of the velocity at the top of the flow.

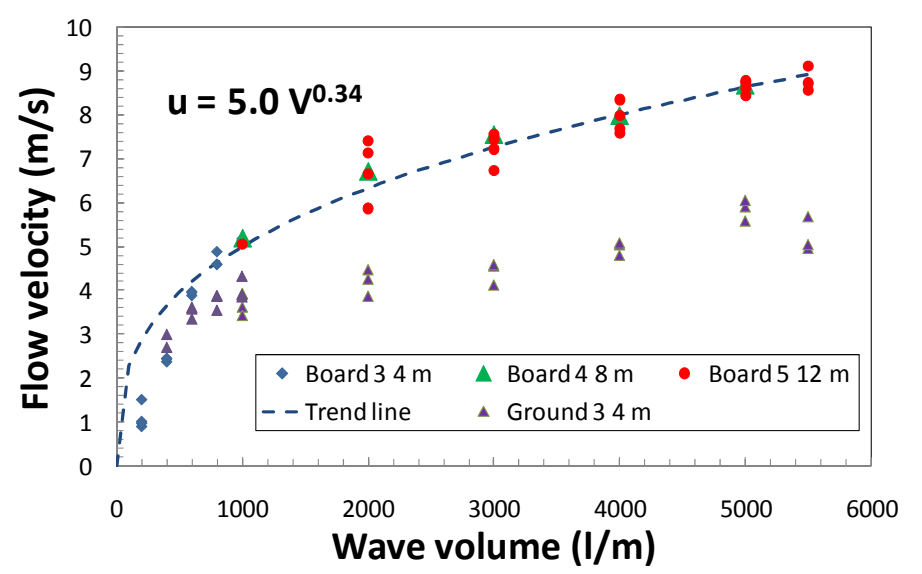

Figure 13. Flow velocities along the slope as function of overtopping wave volumes and compared with flow velocities at ground level.

It has been very difficult to measure flow velocities of overtopping water at real dikes and the surfboard with paddle wheel is a promising development. Another way of measuring the velocity is to measure the front velocity of the overtopping wave. Van der Meer et al. (2009) used a high speed camera to determine this front velocity. But the question that remains is whether the front velocity is equal to the maximum velocity in the flow and/or equal to the depth-averaged velocity.

With the surfboards and paddle wheels it is possible to measure velocity directly, but also front velocities can be calculated as the time difference of the wave front arriving at the paddle wheels or surfboards can be determined (and combined with the known distance between two instruments).

It appeared, after in depth analysis, that every surfboard has its own characteristics when the flow hits the surfboard. As the rise time in tenths of seconds is important and the rising of the surfboard was not identical for each surfboard, it was not possible to determine the front velocities from the flow depth measurements. Only if the distance between the surfboards was large enough, a reliable front velocity could be established. This was the case between surfboards 3 and 5, which were $8 \mathrm{~m}$ apart.

In a few measurements there were paddle wheels at surfboards 4 and 5 and the distance was here $4 \mathrm{~m}$. Paddle wheels respond quickly and are good instruments to look at front velocities.

The front velocities as calculated between surfboards 4 and 5 (flow depth record) and between paddle wheels in surfboards 4 and 5 (velocity record) have been given in Figure 14. The curve in Figure 14 is not a fit to the data, but gives the (maximum) measured flow velocities, given by Eq. 9. 


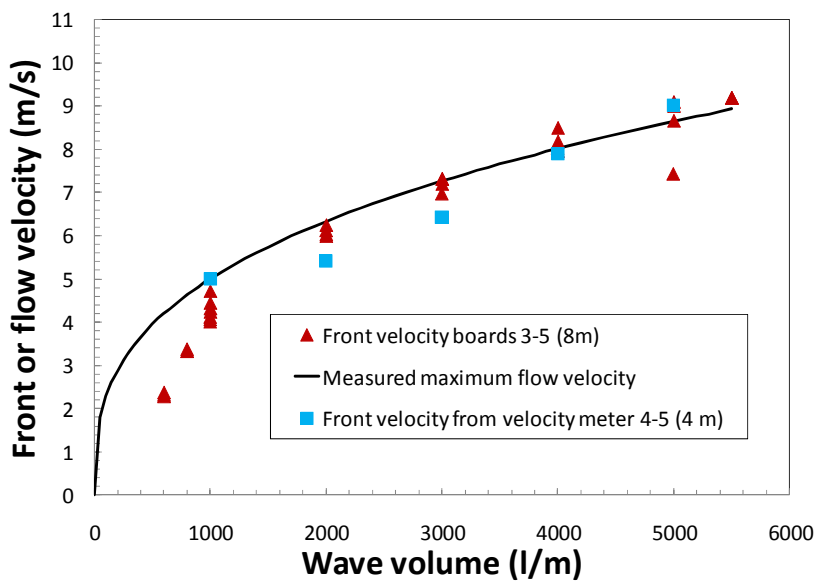

Figure 14. Front velocities calculated from flow depth and flow velocity records, compared with Eq. (9).

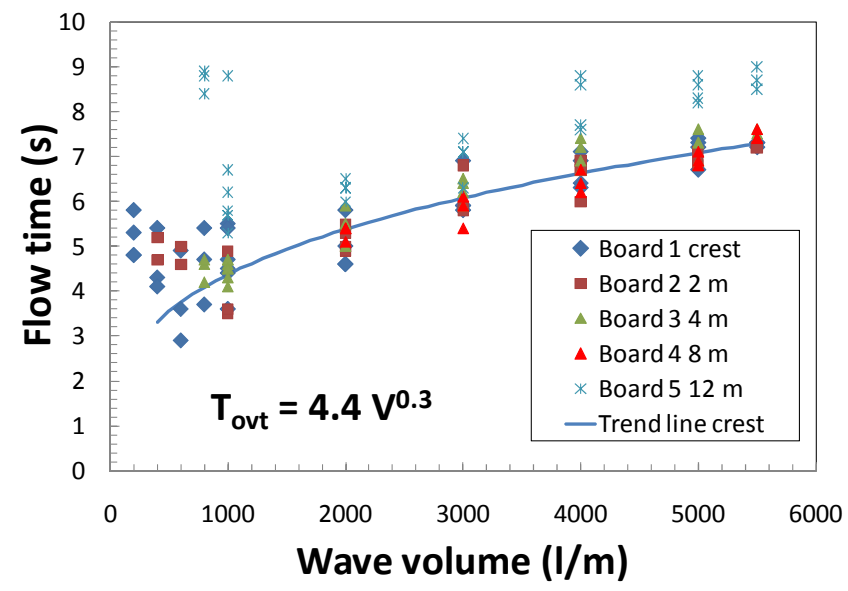

Figure 15. Overtopping durations, $T_{\text {ovt }}$, established from the flow depth records.

The curve in Figure 14 presents nicely the data points. It leads to the important conclusion that front velocities represent well the velocity at the top of the flow as well as the depth-averaged velocity in the layer, as a boundary layer will be very small.

Overtopping durations can be established from the flow depth records. It was hard to determine the overtopping durations for small overtopping wave volumes as water is still flowing a little along the grassed slope when the actual wave has passed already. Also small overtopping wave volumes slowed down the slope and although they were visible at the crest, they were not observed $12 \mathrm{~m}$ further down the slope.

Figure 15 gives the overtopping durations, $\mathrm{T}_{\text {ovt }}$, as they were established from the various flow depth records. There is quite some scatter for overtopping volumes smaller than $1000 \mathrm{l} / \mathrm{m}$, as explained above, but there is a nice trend for larger volumes. The data points show that there is hardly a change in overtopping duration for the first $8 \mathrm{~m}$ on the slope, but there is a slight increase between surfboard 4 and 5 along the more gentle slope. The overtopping duration at the crest can well be described by:

$$
\mathrm{T}_{\text {ovt }}=4.4 \mathrm{~V}^{0.3} \quad\left(\mathrm{~T}_{\text {ovt }} \text { in } \mathrm{s} ; \mathrm{V} \text { in m} \mathrm{m}^{3} / \mathrm{m}\right)
$$

Note that the coefficients in Equations 8-10 are not dimensionless. These three equations give (maximum) flow depth, (maximum) flow velocity and overtopping duration, all three as a function of the overtopping volume. There is also a physical relationship between these variables (mass balance) as integration of flow depth, multiplied by flow velocity (= discharge) over time gives the volume. It is a fairly good assumption that the records of an overtopping wave volume have a triangular shape, see also Figure 10.

This leads then to the following physical relationship, based on the mass balance: 


$$
\mathrm{V}=1 / 3 \mathrm{~h} \mathrm{u} \mathrm{T}_{\text {ovt }}
$$

Combining Equations 8-10 leads to the following equation:

$$
\mathrm{V}^{1.14}=0.34 \mathrm{~h} \mathrm{u} \mathrm{T}_{\text {ovt }}
$$

The power coefficient of 1.14 in Equation 12 is not equal to 1.0 as in Equation 11, but is still close to it, representing a fairly straight line. For a volume of $1 \mathrm{~m}^{3} / \mathrm{m}$ there is almost a perfect match between the coefficients $1 / 3$ and 0.34 . Equations $8-10$ were established independently and based on the similarity between Equations 11 and 12 it can be concluded that Equations 8-10 as a combination fullfill fairly well the requirements for the mass balance.

\section{EROSIONAL INDICES}

The first three years of testing in the Netherlands with the Wave Overtopping Simulator was done for an assumed wave condition of $\mathrm{H}_{\mathrm{s}}=2 \mathrm{~m}$ and $\mathrm{T}_{\mathrm{p}}=5.7 \mathrm{~s}$, being an average wave condition for the Dutch dikes. But estuaries, rivers and small lakes may have design conditions which are smaller, whereas dikes directly facing the North Sea may have larger conditions. It is the crest freeboard that governs the actual overtopping discharge, but the wave conditions determine how overtopping occurs. Larger waves give larger overtopping volumes, but less overtopping waves. From that point of view the overtopping discharge does not describe the full story of wave overtopping, see also Figs. 2 and 3.

The objective of tests with the Wave Overtopping Simulator is to test the erosional strength of the crest and landward slope against wave overtopping. But do different wave conditions indeed give different moments for damage or failure of the grass? Tests performed in February and March 2010 at the Vechtdijk near Zwolle were performed with different wave conditions, in order to establish the influence of wave climate on erosional resistance. The tests have been described by Steendam et al. (2010). The wave conditions are given in Table 2 and can be characterized by wave heights of $1 \mathrm{~m}, 2$ $\mathrm{m}$ and $3 \mathrm{~m}$. A wave height of $1 \mathrm{~m}$ gives almost two times more incident waves in 6 hours than a wave height of $3 \mathrm{~m}$.

\begin{tabular}{|c|c|c|c|c|c|c|c|}
\hline \multirow{2}{*}{\multicolumn{2}{|c|}{ Table 3. Wave overtopping for three wave heights }} & \multicolumn{6}{|c|}{$\begin{array}{l}\text { Mean overtopping discharge } q \\
(\mathrm{I} / \mathrm{s} \text { per } \mathrm{m} \text { ) }\end{array}$} \\
\hline & & 0.1 & 1 & 5 & 10 & 30 & 50 \\
\hline \multirow{4}{*}{$H_{s}=1 \mathrm{~m}$} & Crest freeboard $R_{c}(m)$ & 2.24 & 1.63 & 1.2 & 1.02 & 0.73 & 0.6 \\
\hline & Percentage overtopping waves $P_{o v}$ & 0.7 & 7.2 & 24 & 35.7 & 59 & 70 \\
\hline & Number overtopping waves $N_{o w}$ & 45 & 471 & 1573 & 2336 & 3861 & 4583 \\
\hline & Maximum overtopping volume $V_{\max }(\mathrm{l} / \mathrm{m})$ & 256 & 440 & 831 & 1197 & 2359 & 3401 \\
\hline \multirow{4}{*}{$H_{s}=2 \mathrm{~m}$} & Crest freeboard $R_{c}(m)$ & 5.06 & 3.84 & 2.98 & 2.61 & 2.03 & 1.76 \\
\hline & Percentage overtopping waves $P_{o v}$ & 0.2 & 2.7 & 11.4 & 18.9 & 36.6 & 47 \\
\hline & Number overtopping waves $N_{o w}$ & 9 & 126 & 525 & 867 & 1683 & 2160 \\
\hline & Maximum overtopping volume $V_{\max }(\mathrm{l} / \mathrm{m})$ & 769 & 1222 & 2018 & 2697 & 4707 & 6387 \\
\hline \multirow{4}{*}{$H_{s}=3 \mathrm{~m}$} & Crest freeboard $R_{c}(m)$ & 7.98 & 6.16 & 4.89 & 4.35 & 3.48 & 3.08 \\
\hline & Percentage overtopping waves $P_{o v}$ & 0.085 & 1.49 & 7.05 & 12.3 & 26.1 & 34.9 \\
\hline & Number overtopping waves $N_{\text {ow }}$ & 3 & 55 & 262 & 456 & 972 & 1300 \\
\hline & Maximum overtopping volume $V_{\max }(\mathrm{l} / \mathrm{m})$ & 1424 & 2254 & 3478 & 4509 & 7375 & 9709 \\
\hline
\end{tabular}

\begin{tabular}{|l|c|c|c|}
\hline \multicolumn{4}{|c|}{ Table 2. Wave conditions simulated at the Vechtdijk, Zwolle } \\
\hline Seaward slope 1:4 & \multicolumn{4}{|c|}{ Wave height $\boldsymbol{H}_{\boldsymbol{s}}$} \\
\cline { 2 - 4 } Test duration 6 hours & $\mathbf{1 ~} \mathbf{~}$ & $\mathbf{2 ~} \mathbf{~}$ & $\mathbf{3 ~} \mathbf{~}$ \\
\hline Peak period $\boldsymbol{T}_{\boldsymbol{p}} \mathbf{( s )}$ & 4.0 & 5.7 & 6.9 \\
\hline Mean period $\boldsymbol{T}_{\boldsymbol{m}} \mathbf{( s )}$ & 3.3 & 4.7 & 5.8 \\
\hline Number of waves $\boldsymbol{N}_{\boldsymbol{w}}$ & 6545 & 4596 & 3724 \\
\hline Run-up, $\mathbf{R u}_{\mathbf{2} \%}(\mathbf{m})$ & 1.99 & 3.98 & 5.94 \\
\hline
\end{tabular}


The three wave conditions give different overtopping parameters, like the crest freeboard, percentage of overtopping waves, number of overtopping waves and largest overtopping wave volume, all related to a certain overtopping discharge. All these values have been given in Table 3 . A wave height of $1 \mathrm{~m}$, for example, gives for an overtopping discharge of 10 1/s per $\mathrm{m} 2336$ overtopping waves in 6 hours. For a $3 \mathrm{~m}$ wave height this reduces to 456 overtopping waves, which is only $20 \%$ of the number for $1 \mathrm{~m}$ waves, but the overtopping discharge is the same. It is clear that the larger wave height will then give larger overtopping volumes, which in this example is $4.5 \mathrm{~m}^{3} / \mathrm{m}$ as largest volume for a 3 $\mathrm{m}$ wave height and only $1.2 \mathrm{~m}^{3} / \mathrm{m}$ for a $1 \mathrm{~m}$ wave height.

The Vechtdijk was a $100 \%$ sandy dike, covered with only $0.15 \mathrm{~m}$ of soil and grass. It was expected that failure of the grass would certainly be achieved for each of the wave conditions and probably for different overtopping discharges. This was, however, not always the case due to early failure of a tree in the slope and a particular transition (see Steendam 2010) and it was not always possible to reach failure of the grassed slope itself.

It became also clear that it is not so easy to decide when a grassed slope has start of damage, developing damage or failure. Failure is the most easy definition: the sand core underneath the soil layer becomes free and damage develops fast. Start of damage would actually be the first small hole in the grass cover and this is not a consistent parameter as it may depend on the existence or nonexistence of one weak spot on a fairly large surface. A more consistent definition would be "various damaged locations", meaning that it does not depend solely on one weak spot. In the case the grassed slope did not fail the condition "no failure" became also a criterion.

In summary the following damage criteria were used:

- $\quad$ First damage (Figure 16)

- Various damaged locations (Figure 17)

- $\quad$ Failure (Figure 18)

- $\quad$ Non-failure after testing (Figure 19)

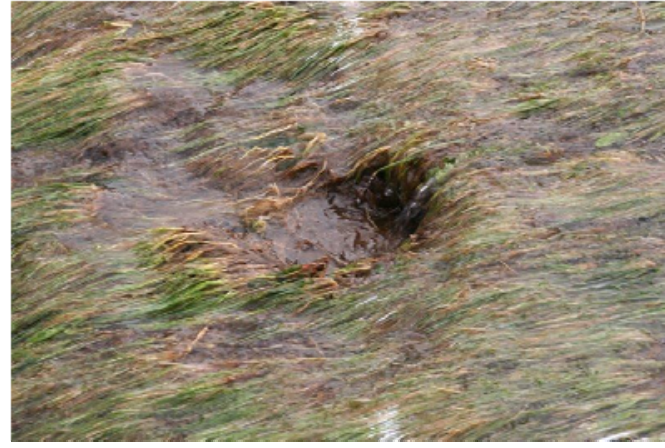

Figure 16. First damage.

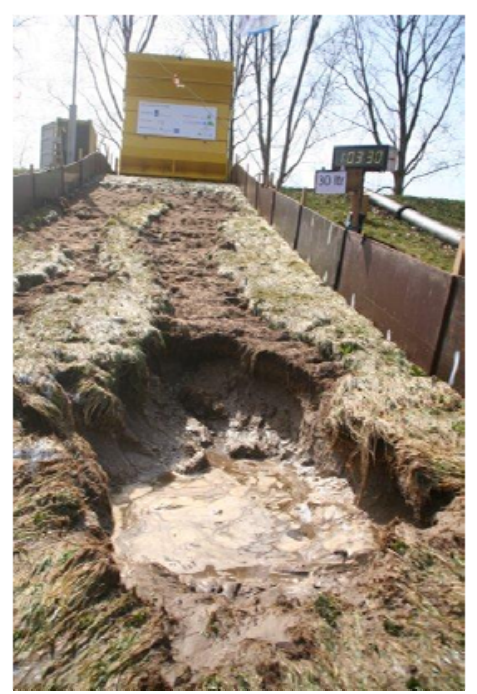

Figure 18. Failure.

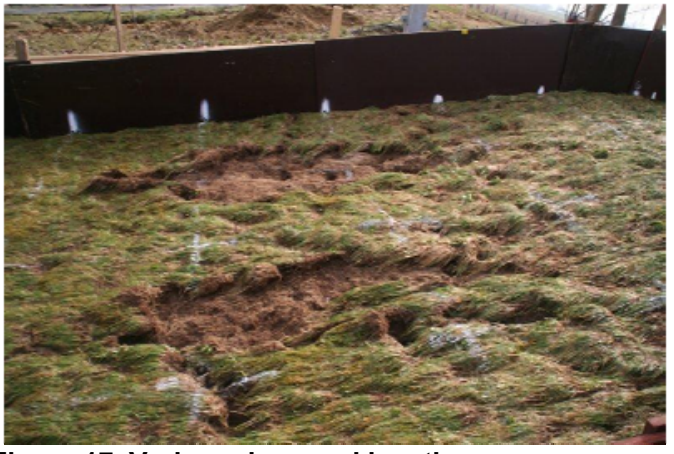

Figure 17. Various damaged locations

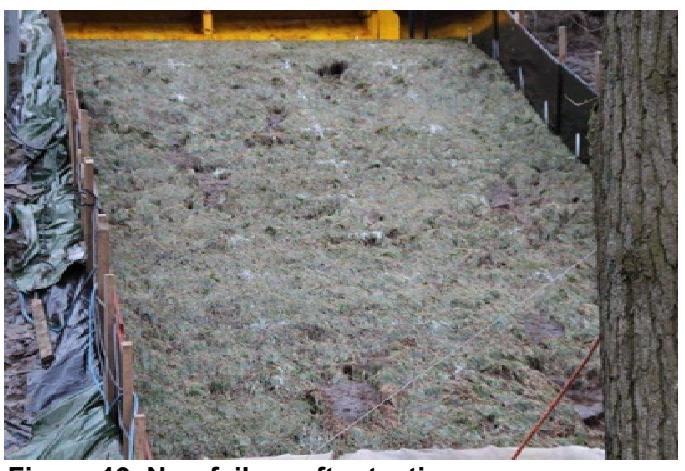

Figure 19. Non-failure after testing 
The theory of shear stress with a threshold was taken as a basis for development, see also Hoffmans et al. (2008). The development, however, took place at the same time when Dean et al. (2010) worked on their erosional equivalence, but it was not yet published at that time. Dean et al. (2010) considered three possible developments, which in essence can be described as follows:

$$
\begin{aligned}
& \text { Erosion due to excess velocity: } E=K \Sigma\left(\left(u-u_{c}\right) t\right) \quad[m / s] \\
& \text { Erosion due to excess shear stress: } E=K \Sigma\left(\left(u^{2}-u^{2}{ }_{c}\right) t\right) \quad\left[\mathrm{m}^{2} / \mathrm{s}\right] \\
& \text { Erosion due to excess of work: } E=K \Sigma\left(\left(u^{3}-u^{3}{ }_{c}\right) t\right) \quad\left[\mathrm{m}^{3} / \mathrm{s}\right]
\end{aligned}
$$

In all cases the velocity of the overtopping wave plays a role and a critical velocity, which should be exceeded before erosion will take place. In the equations also the time that the critical velocity is exceeded, is important.

The analysis of the Vechtdijk results had as basis Equation 14 (Hoffmans et al. 2008). The testing showed indeed that only waves of a certain volume (or velocity) damaged the slope. Smaller volumes did not contribute to the development of damage. This confirms the use of a threshold like $\mathrm{u}_{\mathrm{c}}$. But one main modification was made, based on observed behaviour during testing. In Equations 13-15 the time that $\mathrm{u}_{\mathrm{c}}$ is exceeded is taken into account. The origin of this comes from tests with continuous overflow, where indeed time, or the duration that the flow is present, is important.

But (severe) wave overtopping is different from continuous overflow. First of all, velocities in an overtopping wave are much larger than velocities in continuous overflow, for the same discharge. Secondly, the duration that $u_{c}$ is exceeded in an overtopping wave is quite short, in the order of 1-3 s, and this duration is fairly constant and in total much shorter than for continuous overflow.

The observation of overtopping waves has taught us that a wave front rushes over the slope with large velocity. Within tenths of seconds (see Figure 10) the maximum velocity is reached. The grass feels this as a kind of "impact" and it is this impact that causes initiation or further development of damage. It is believed that this impact is more important than the duration of the overtopping wave above a certain threshold. For this reason Equation 14 was rewritten to an erosional index called "cumulative hydraulic load", where the actual time or duration for an overtopping wave was omitted:

$$
\text { Cumulative hydraulic load: } \Sigma\left(\mathrm{u}^{2}-\mathrm{u}_{\mathrm{c}}^{2}\right) \quad\left[\mathrm{m}^{2} / \mathrm{s}^{2}\right]
$$

With known distributions of overtopping wave volumes (Eqs. 1 and 2) and known velocities per overtopping wave volume (Eq. 9) it is possible to calculate the cumulative hydraulic load for each wave overtopping condition, or a number of tests, to a certain moment when a damage criterion is reached. And the cumulative hydraulic load depends of course on the critical velocity $u_{c}$ that is taken.

The main question is then: what is the critical velocity, $u_{c}$, that brings the damage observed for different hydraulic regimes, together?

The four damage criteria (see Figures 16-19) were taken for all tests and the results were compared for critical velocities of $0 ; 3.1 ; 4.0 ; 5.0$ and $6.3 \mathrm{~m} / \mathrm{s}$, which are in accordance with overtopping wave volumes of $0 ; 0.25 ; 0.5 ; 1$ and $2 \mathrm{~m}^{3} / \mathrm{m}$. Figures $20-22$ give the comparison for the extremes ( 0 and 6.3 $\mathrm{m} / \mathrm{s}$ ) and for $4.0 \mathrm{~m} / \mathrm{s}$.

The transition and the tree for a wave height of $2 \mathrm{~m}$ failed before the grass failed and the test had to be stopped before grass failure could be reached. These are the columns for "non-failure". The grass did fail, however, for the tests with $1 \mathrm{~m}$ and $3 \mathrm{~m}$ wave height, each after a different test duration. The section for $1 \mathrm{~m}$ wave height failed after 6 hours tests with $0.1 ; 1 ; 10 ; 301 / \mathrm{s}$ per $\mathrm{m}$ and another 2:07 hours with $50 \mathrm{l} / \mathrm{s}$ per $\mathrm{m}$. The section with $3 \mathrm{~m}$ wave height failed after 6 hours tests with $0.1 ; 1 ; 101 / \mathrm{s}$ per $\mathrm{m}$ and another 1:03 hour with $30 \mathrm{l} / \mathrm{s}$ per $\mathrm{m}$. The large wave height gave earlier damage and for both wave heights the damage was mainly caused by many mole holes just below the crest.

Figures 20-22 can be used to establish the correct critical velocity for this dike section. If the height of the columns in the graphs are equal, then the correct critical velocity is found. As "nonfailure" is only found for one wave height of $2 \mathrm{~m}$ and "first damage" is not very reliable, the most interesting columns are those for "various damages" and for "failure". Both Figures 20 and 22 show that the columns have different height. The best graph is given in Figure 21, where the critical velocity used was $4 \mathrm{~m} / \mathrm{s}$. This is the critical velocity that should be used for this sandy dike. 


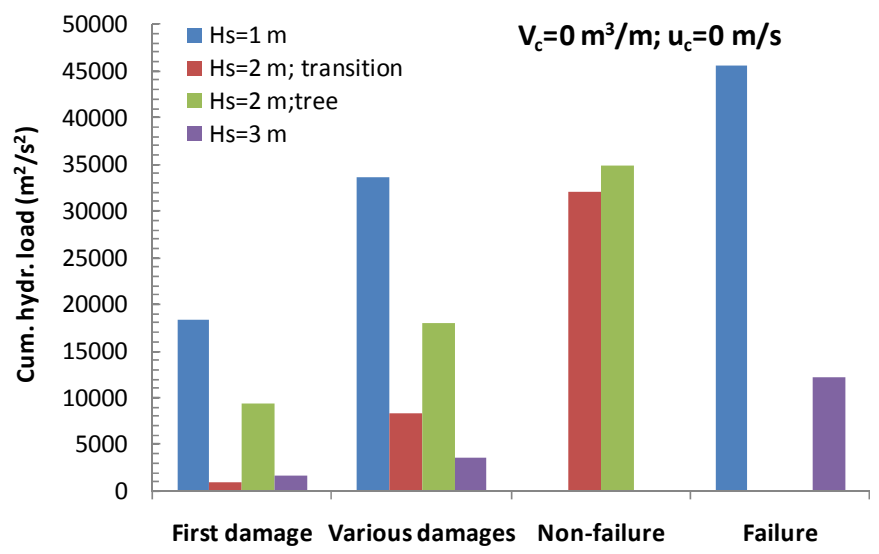

Figure 20. Comparison of cumulative hydraulic loads for various damage criteria; $u_{c}=0 \mathrm{~m} / \mathrm{s}$.

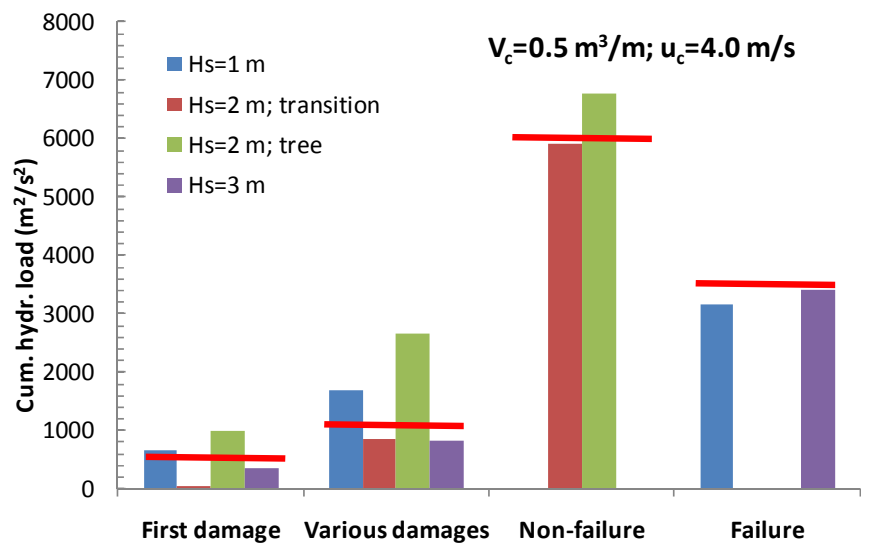

Figure 21. Comparison of cumulative hydraulic loads for various damage criteria; $u_{c}=4 \mathrm{~m} / \mathrm{s}$.

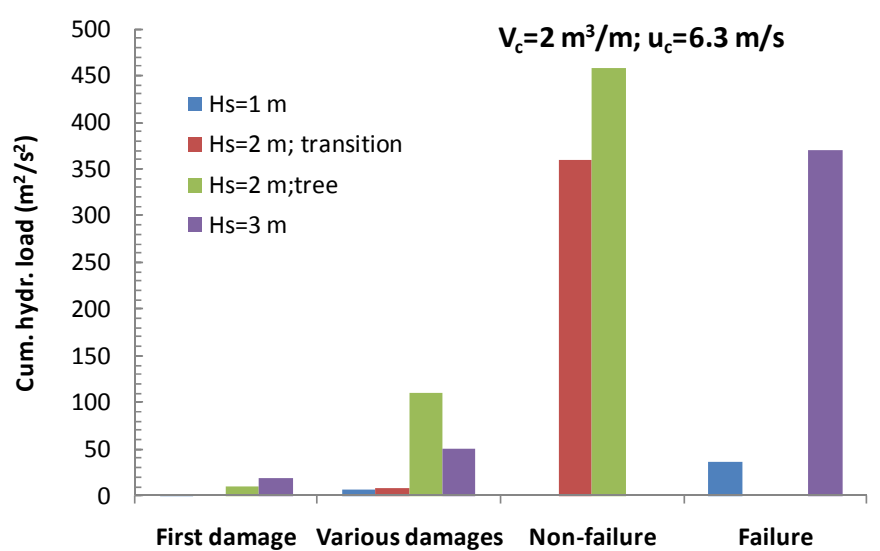

Figure 22. Comparison of cumulative hydraulic loads for various damage criteria; $u_{c}=6.3 \mathrm{~m} / \mathrm{s}$.

Based on Figure 21 the following conclusions can be made for the Vechtdijk and the limits are given in the graph:

- A critical velocity should be used of $u_{c}=4 \mathrm{~m} / \mathrm{s}\left(\mathrm{V}_{\mathrm{c}}=0.5 \mathrm{~m}^{3} / \mathrm{m}\right)$

- Start of damage: $\quad \Sigma\left(\mathrm{u}^{2}-\mathrm{u}_{\mathrm{c}}^{2}\right)=500 \mathrm{~m}^{2} / \mathrm{s}^{2}$

- Various damaged locations: $\quad \Sigma\left(\mathrm{u}^{2}-\mathrm{u}_{\mathrm{c}}{ }^{2}\right)=1000 \mathrm{~m}^{2} / \mathrm{s}^{2}$

- Failure (by mole holes): $\quad \Sigma\left(\mathrm{u}^{2}-\mathrm{u}_{\mathrm{c}}^{2}\right)=3500 \mathrm{~m}^{2} / \mathrm{s}^{2}$

- Non-failure for normal slope: $\Sigma\left(\mathrm{u}^{2}-\mathrm{u}_{\mathrm{c}}{ }^{2}\right)<6000 \mathrm{~m}^{2} / \mathrm{s}^{2}$ 
A confirmation of above analysis and conclusions could be established by looking at the damage on the slope after the hydraulic measurements. Here only about 40 overtopping waves rushed down the slope instead of many hours like for normal testing, but many large volumes were present. The hypothesis of cumulative hydraulic load should work for many hours of testing, but also for the "artificial" distribution of a small number, but mainly very large overtopping waves.

The observation of the slope after the hydraulic measurements could best be described as "various damaged locations". A number of small holes were observed and one location with a little larger damaged area.

The cumulative hydraulic load for these 40 waves, using $\mathrm{u}_{\mathrm{c}}=4 \mathrm{~m} / \mathrm{s}$, amounted to $946 \mathrm{~m}^{2} / \mathrm{s}^{2}$. This is very well comparable with the $1000 \mathrm{~m}^{2} / \mathrm{s}^{2}$ that was given for this damage criterion. It can be concluded that this very short session of large waves can very well be compared with many hours of testing of real wave overtopping. The analysis confirmed the hypothesis of cumulative hydraulic load.

In future also the method of "excess of work" (Equation 15), which was preferred by Dean et al. (2010), should be elaborated, maybe with ongoing work in the US with a new Wave Overtopping Simulator. The reason for Dean et al, however, to choose for excess of work instead of excess of shear stress was that excess of work fitted better to known stability curves for continuous overflow, not wave overtopping. Dean et al. (2010) did not possess the results of simulation of wave overtopping at real dikes as in the Netherlands.

Another difference between the two methods is the value of the critical velocity $u_{c}$. Based on continuous overflow critical velocities are in the range of 1-2 m/s. But the very "weak" Vechtdijk (sand with a very thin layer of soil with grass) needs a critical velocity of $4 \mathrm{~m} / \mathrm{s}$ and this can be considered as a lower boundary. Other dike sections tested need probably a critical velocity in the range of 5-7 m/s. It is, therefore, still an open question which method would work best with real wave overtopping at dikes.

\section{CONCLUSIONS AND RECOMMENDATIONS}

Improved equations (Eqs. 5-7) for flow depth and flow velocity under wave overtopping at the crest of dikes or levees have been developed, using new data from the Hydralab Flowdike project. The present knowledge, however, on flow depth, flow velocity and overtopping duration are not consistent with the mass balance. More research is required to solve this discrepancy and probably the flow depth and velocity must become more dependent on wave period. Also the assumption about both flow depth and flow velocity having a Rayleigh distribution may be questioned.

Successful hydraulic measurements have been performed at the slope of a real dike under wave overtopping simulation. Analysis gives flow depth, flow velocity and overtopping duration as a function of overtopping wave volumes (Eqs. 8-10). The combination of these equations fulfill fairly well the requirements for the mass balance. These equations are only valid for the Dutch Wave Overtopping Simulator.

The measurements confirm that the boundary layer of the turbulent aerated flow during wave overtopping at a grass covered slope is very small and that the front velocity can be considered equal to the depth-averaged maximum velocity as well as to the velocity on top of the flow.

It is important to use various damage descriptions or criteria in order to describe the behaviour of a grass covered landward slope under wave overtopping. Useful criteria, based on testing at a real dike with the Wave Overtopping Simulator, were: first damage; various damaged locations; failure and nonfailure after testing.

The erosional index "cumulative hydraulic load" was developed, which to a certain extent is comparable with the erosional equivalence of Dean et al. (2010). The method is based on excess of shear stress and not on excess of work. Tests at the sandy Vechtdijk with three different wave heights showed that a critical velocity of $u_{c}=4 \mathrm{~m} / \mathrm{s}$ was needed to give similar damage for similar cumulative hydraulic loads. The method was confirmed by the damage after the hydraulic measurements, which was caused by only 40 overtopping waves instead of many hours of real overtopping simulation. As the Vechtdijk was a "weak" slope (sand covered with $0.15 \mathrm{~m}$ of soil and grass) it can be expected that for better grass covers the critical velocity may increase to 5 or $6 \mathrm{~m} / \mathrm{s}$ or even more.

It is recommended to compare, elaborate and improve the two methods of erosional equivalence and cumulative hydraulic load for more situations, maybe with ongoing work in the US with their new Wave Overtopping Simulator. 


\section{ACKNOWLEDGMENTS}

All Dutch tests with the Wave Overtopping Simulator were conducted under the SBW-project (Strength and Loads on Water Defences) of the Ministry of Transport, Public Works and Water Management, Rijkswaterstaat.

The model tests under the Flowdike project were conducted by RWTHUG, Aachen, in the Shallow Water Basin at DHI, Denmark, under Contract Number 022441 of the European Community Structuring the European Research Area - Research Infrastructures. The financial contribution from the EC is appreciated.

\section{REFERENCES}

Bosman, G, J.W. van der Meer, G. Hoffmans, H. Schüttrumpf and H.J. Verhagen. 2008. Individual overtopping events at dikes. ASCE, proc. ICCE 2008, Hamburg, Germany, p. 2944-2956.

Dean, R.G., J.D. Rosati, T.L. Walton and B.L. Edge (2010). Erosional equivalences of levees: Steady and intermittent wave overtopping. Journal of Ocean Engineering 37 (2010) 104-113.

EurOtop Manual. 2007. Wave Overtopping of Sea Defences and Related Structures - Assessment Manual. UK: N.W.H. Allsop, T. Pullen, T. Bruce. NL: J.W. van der Meer. DE: H. Schüttrumpf, A. Kortenhaus. www.overtopping-manual.com.

Hoffmans, G., G.J. Akkerman, H. Verheij, A. van Hoven and J.W. van der Meer. The erodibility of grassed inner dike slopes against wave overtopping. ASCE, Proc. ICCE 2008, Hamburg, p. 3224-3236.

Schüttrumpf H. and H. Oumeraci (2005). Layer thicknesses and velocities of wave overtopping flow at seadikes. Journal of Coastal Engineering, Volume 52, Issue 6, p. 473-495.

Schüttrumpf, H. and M.R.A. van Gent, 2003. Wave overtopping at seadikes. ASCE, proc. Coastal Structures 2003, p. 431-443.

Schüttrumpf, H.F.R. 2001. Wellenüberlaufströmung bei See-deichen, Ph.D.-thesis, Technical University Braunschweig.

Steendam, G.J., J.W. van der Meer, B. Hardeman and A. van Hoven (2010). Destructive wave overtopping tests on grass covered landward slopes of dikes and transitions to berms. ASCE, Proc. ICCE 2010, Shanghai, China.

Van Gent, M.R.A. 2002. Low-exceedance wave overtopping events. Delft Hydraulics project id. DC030202/H3803.

Van der Meer, J.W., R. Schrijver, B. Hardeman, A. van Hoven, H. Verheij and G.J. Steendam. 2009. Guidance on erosion resistance of inner slopes of dikes from three years of testing with the Wave Overtopping Simulator. Proc. ICE, Breakwaters, Marine Structures and Coastlines; Edinburgh, UK.

Van der Meer, J.W., G.J. Steendam, G. de Raat and P. Bernardini. 2008. Further developments on the wave overtopping simulator. ASCE, proc. ICCE 2008, Hamburg.

Van der Meer, J.W., P. Bernardini, G.J. Akkerman and G.J.C.M. Hoffmans, 2007. The wave overtopping simulator in action. ASCE, proc Coastal Structures, Venice, Italy, p. 645-656.

Van der Meer, J.W., W. Snijders and E. Regeling, 2006. The wave overtopping simulator. ASCE, proc. ICCE 2006, San Diego, p. 4654-4666. 